\title{
Research on the Path of College Students' Patriotism Education in the Self-Media Era
}

\author{
Zhao Liu and Cuiyan Gong
}

\author{
School of Electrical Engineering and Electronic Infromation ;Xihua university Chengdu 610039 , \\ China
}

1250680088@qq.com,504579367@qq.com

\section{Keywords: Self-media; Patriotism education; College students; Path}

\begin{abstract}
With the advent of the self-media era, there are increasing ways for college students to acquire various kinds of information and knowledge. At the same time, the change in ideology will also uproar. Some negative information on networks and media will affect young student, especially in the aspect of patriotic ideologies. Therefore, the requirement of patriotism education has been proposed, and varied paths of patriotic education has been conducted by the higher educational institutions within the self-media environment. The research will shed light on the problem that how to facilitate current college students actively take actions to self-educate and spread patriotism in the self-media environment.

The rapid development of China's economy and the in-depth, full-scale popularization and application of the Internet indicate the coming of the media era. Self-media tools such as WeChat, Weibo, and blogs have rapidly penetrated everyday life of college students, which has broken the informational monopoly by traditional media. With the characteristics of individualized, short and fragmented language, explosive transmission, self-media channels are favored and sought after by young college students, which has led to changes in values, thinking patterns, and behaviors. This transformation is both beneficial and disadvantageous for ideological as well as political education in colleges and universities. It is very convenient to obtain access to more valuable information, but at the same time are more tended to be affected by biased or extreme information on the media thus may lead to dangerous actions and opinions about history, certain events and social figures, or even the society as a whole.
\end{abstract}

Therefore, ideological and political education for college students in the self-media age is a priority. The path and methods for patriotic education will be discussed in deep.

\section{Changes in the Mindset of College Students in Self-media Era}

This is the best time and the worst time. This is more true for college students. This best time represent itself in the following aspects:

Firstly, the living conditions have been largely promoted. With the continuous development of economy, the country has basically waved a farewell to the era of poverty and hunger. Nowadays, college students have upgrading needs for daily items like food and clothing. The self-media tools such as WeChat and Weibo become important platforms to acquire of information to meet students' growing and verified needs.

Secondly, the way of learning is diversified. Since the arrival of the media era, the traditional ways of teaching, through textbooks, newspapers and teachers, have been completely changed. Self-media channels provide college students abundant knowledge through the development of Internet technology and participation of the mass. More importantly, the knowledge on line seems to be more instant and can better catch up with the times. This provides new methods for college students to understand China and the world.

Thirdly, self-media provides self-integration and promotion. Due to the extensive use of the self-media tools, industries are using self-media platforms, such as WeChat's circle of friends, to promote products and corporate image. Undergraduates catch up with this trend and they also chose to integrate and promote themselves. For example, through the WeChat's circle of friends, they 
express their own opinions on business projects, personal feelings and family issues, and opinions on social hot issues. They also seek understanding and familiarization from friends in the circle. The self-media tools shorten interpersonal distance and become convenient, instant and personalized display platforms. This is also a popular way for college students to promote themselves and their understanding of the world. In addition to this, college students will constantly learn new smart technologies and use the self-media platforms to showcase their interests or ideas. With the music and self-media's integration, students can use the smart phone to shoot micro-adapted music video. The videos are widely spread on the Internet through WeChat, Weibo. Among them, there are micro-films with the producer as one of the protagonists, thus to realize their own movie dreams.

But for college students, this is also the worst era. In the era of self-media, anyone can express their opinions. Information on networks is too large and difficult to distinguish between true and false, which presses a negative impact on formation and development of college students' values. The online "Global Village" is almost borderless, so the college students are vulnerable to negative and extreme information from aboard. Being exposed to deliberately defame, demonizing or even vilifying information about China, college students might weaken their patriotism feelings over time. Patriotic enthusiasm could be reduced, and even words of rebellion might appear. Therefore, in the era of self-media, patriotism education for college students becomes a major educational issue.

\section{Basic Requirements of Patriotism in Self-media Era}

With such a large amount of information, college students have more convenient access to information in the self-media era. Patriotic education should be specified from particular aspects, so that students can hold on to the bottom line of some patriotic requirements.

Firstly, political and ideological teaching methods in universities should be strengthen and modernized. One of the vital tasks undertaken by political and ideological education in colleges and universities is to enhance students' patriotism, and foster their aspiration to become useful talents for the construction of the motherland in the future. In classroom education, with the assistants of self-media tools, students' development can be combined with specific events to demonstrate the importance of patriotism to students on the ground.

Secondly, teams of high-quality political counselor should be build. Political counselor is on the top of daily contact list for college students, and their words and deeds often directly exert tangible and intangible influence on students' thoughts and actions. Political counselor should be regarded as a main role in the patriotism education.

Thirdly, the education of traditional Chinese culture should be strengthened. The Chinese nation has a splendid culture and a long history. There are many aspects that students should seriously study and learn from. However, due to the popularity of the Internet and the use of smart phones, students spend a lot of time on entertainment or social networking and few of them would meditate on traditional cultural knowledge. If forced to instill the learning, there is clearly a great conflict with the current values and wishes of students. By utilizing the functions of self-media, the students will learn or interpret and disseminate the essence of traditional culture through their own methods through WeChat, Weibo, and QQ. This is a better path to strengthen patriotic education. Through the student's own mobile phone, the theory and knowledge in traditional culture can be referred to and applied anywhere and anytime. In the form of self-media materials, it would be fun and entertaining to assist the spreading and acceptance of Chinese traditional culture for college students.

Fourthly, school management should be reinforced. The daily life of college students is mostly carried out within the campus. Therefore, the school is the main position for college students to accept patriotic education. When conducting patriotic education, it is imperative to strengthen school's management from teachers and counselors to administrators, staff members should have patriotic awareness, and form harmonious and positive atmospheres and environments. That would be assistances for the students to strengthen their patriotism, avoiding the mind swings or indetermination. 


\section{Effective Path of Patriotic Education for College Students in Self-media Age}

On the basis of above-mentioned basic requirements for ideology and patriotic education in self-media age, the effective paths of patriotic education for college students are proposed as follows:

Firstly, college students should be notified with the current developmental trends of domestic environments and only by that can students understand their own social tasks. China is currently in a period of rapid social development. Political and social reform has also entered a deeper level. The living standards of the people are constantly improved, so as the aspirations and needs of people. For future college students, they are expected to shoulder responsibilities for national revival and prosperity. Firm confidence and sense of responsibility for motherland should be erected during the patriotic education.

Secondly, schools should guide patriotic practices by applying the tools favored by students. For example, the "Douyin" app spreads widely among young students and can be employed to display the splendid history of China with deepened conception of traditional culture. So more students could have the sense of honor and patriotic consciousness will inevitably be strengthened. In addition to this, it is also possible to use other forms of self-media to display and retrospect specific events or the historical moments, combining patriotism with prevalent elements.

Finally, enhance the legal consciousness of college students in patriotic education. China is building a legal society and various laws and regulations have been introduced and implemented. Since there are lack of education for undergraduates to acquire specific legal knowledge, it still exists lack of legal awareness and legal thinking. Impulsive or overactive practices are often conducted when college students encounter difficulties. The situation is the same for patriotic education. When confronted with behaviors endangering national security or harming country, society, and individuals, the students should seek solutions in a legal way.

\section{Reference}

[1] X. L.Duan: The Ideological and Political Education in Colleges and Universities in the New Media Age: Problems and Reforms[J]. Theoretical observation(2014)No.11, 141-142.

[2] X. L .Duan: Research on College Students' Patriotism Education in the Era of Media(MS. Guizhou Normal University, China2015)

[3] N.Lu: On College Students Conducting Correct Patriotism Education Research.( MS.,Taiyuan University of Technology, Taiyuan, China(2012)..

[4] B.L.Xiao, Y.Han: The Reason and Emotion to Deal with Pride and Prejudice_Patriotism in the Internet Age[J]. Information Network Security(2008)No.7, 47-49.

[5] F. Yang: The Situation and Countermeasures of Patriotism Education for College Students in the Era of Media[J]. Journal of North China Institute of Water Resources and Hydropower University (Social Science Edition) (2016)No.2, 124-126.

[6] Q.Yang: Research on the Actual Effect of Self-media on University Students' Patriotism Education [J]. Education and Teaching Forum.(2016)No.37, 53-54. 